\title{
The Economic Consequences of Divorce in Germany: What Has Changed since the Turn of the Millennium?
}

\author{
Miriam Bröckel, Hans-Jürgen Andreß
}

\begin{abstract}
Our analysis of data from almost 30 waves of the German Socio-Economic Panel Study (SOEP) shows that the economic consequences of divorce are still more negative for women than for men despite increased female labour force participation and, correspondingly, increased numbers of dual earner households. After reviewing recent shifts in the institutional fabric and the social structure of the conservative German welfare state with respect to families and marriage, the empirical analysis investigates the economic consequences of a sample of 844 men and 1,006 women in five dimensions: child custody, support payments, housing, employment, and economic well-being. Change is measured by comparing data from before and after the turn of the millennium.

Overall, the analyses show that the economic consequences of divorce are still more negative for women than for men after the turn of the millennium, although female labour participation has increased and the public child care system was expanded. Nevertheless, some signs of change become visible indicating that the gains and losses of marital disruption are not unilaterally distributed among the genders. That men may also depend on incomes of their spouses can be seen for the increasing number of dual earner households. Moreover, after the turn of the millennium, economic dependence on public transfers increased not only for women but also for men.
\end{abstract}

Keywords: Divorce consequences $\cdot$ Household income $\cdot$ Gender inequalities $\cdot$ SOEP

\section{Introduction}

About a decade ago, we provided evidence on changes in material well-being that accompany marital disruption in Germany (Andreß et al. 2003; Andreß/Bröckel 2007). ${ }^{1}$ Our analyses were among the first to provide a comprehensive picture of

1 At various places in this article, we repeat conclusions from our former work. For reasons of readability, we do not cite them explicitly unless they refer to concrete data. 
men's and women's occupation, income, housing, living conditions, unemployment and welfare dependency before and after separation. We found clear-cut gender inequalities among the separating men and women. Women took care of children after separation more often than men, but were only partly rewarded for their care work by support payments from their former spouse. When there were minor children in the household after separation, mothers also moved out of their home more often than fathers did. The tight economic situation of their households led many women to increase their employment after separation, especially women living together with children. Most men, on the other hand, were employed full-time during marriage, and had therefore already exhausted their employment capacities. Contrary to public opinion, decreased employment among separated men was somewhat rare. As a result of all these changes in household composition, support payments, employment and residential mobility, women ended up with much lower average disposable household incomes than during marriage, especially when taking the number of dependents into account. After housing costs had been deducted, women's equivalised household incomes one year after separation equalled two-thirds of men's; women lost one-third of their pre-separation household income, while men lost a little more than one-tenth (Andreß/Bröcke/ 2007: 221-222).

These gender inequalities were not unexpected, and were in line with international research on the economic consequences of partnership dissolution (Andreß et al. 2006: Table 1). Four risk factors are usually identified for women (Holden/ Smock 1991. 68; Sørensen 1994: 173):

1. After separation, if there are children, economic needs are higher for the resident parent, which in most cases is the mother. Because she has to care for more economically dependent household members, she is often restricted in her earning capacities, especially if child care facilities are scarce.

2. Moreover, the risk that the resident parent does not receive the necessary child maintenance costs from the non-resident liable parent is high.

3. Income sharing during marriage allows women to participate in men's market incomes, which are higher than women's market incomes on average. It is questionable whether the amount of maintenance payments received from their former spouse after separation compensates for the reduction in economic support compared to what women received during marriage.

4. Finally, changes in material wealth, pension entitlements, and human capital that both partners experience during marriage are only imperfectly measurable and therefore hard to equalise after separation. ${ }^{2}$ This is especially true for the gains and losses in human capital. Given the frequent division of labour with a husband employed full-time and a wife working part-time (at most) who takes care of the household and the children, it is probable that the gains in human capital by continued employment on the side of the husband (Kenny 1983) are not set off against the losses of human capital resulting from interrupted or delayed working careers on the side of the wife.

2 Even if such changes are measurable, the economic loss may be high when they are sold to pay off the partner (e.g. in case of property). 
The magnitude of these risks is naturally moderated by the institutional context in which marital disruptions take place. For example, with respect to the first risk, if the welfare state provides public child care, this would enable resident parents to participate in the labour market despite their family obligations. ${ }^{3}$ Moreover, the number of jobs available for both genders that pay a living wage depends on the structure of the labour market. Finally, anti-discrimination legislation may reduce potential gender wage gaps. Concerning the second risk, the legal system may provide measures and enforcement procedures to ensure that non-resident parents pay the necessary maintenance costs for their children and that the better-off spouses make support payments for their former spouses, which would minimise the third risk. Looking, finally, at the fourth risk, legal procedures may exist that equalise material wealth and pension entitlements accrued by both partners during marriage. Moreover, employment-friendly policies may support women's continued employment during marriage, thus minimising losses of human capital due to interrupted or delayed working careers.

Ten years ago, we argued that the conservative German welfare state model is characterised at least historically by strong support for the male breadwinner family (Andreß/Bröcke/ 2007: 196-202). Given this dependence on the male breadwinner model, one would expect marital disruption to be much more consequential for German women than for women in other countries. On the other hand, since the German welfare state relied so heavily on the male breadwinner model, German maintenance law at that time included rather extensive support regulations for the economically-dependent spouse and children. ${ }^{4}$ In addition, a rather comprehensive system of public transfers cushioned the most severe economic consequences of marital disruption. We therefore had less strong expectations, and hypothesised that the economic consequences of marital disruption may be negative for German women, but not as severe as might be expected from a male breadwinner model without safeguards. Indeed, our empirical analyses showed that the negative effects of the male breadwinner model on material well-being after marital disruption were attenuated, but less so by the legal system or the support payments resulting from it. It was rather the generous German system of income support that cushioned the most severe negative changes.

Our analysis was based on longitudinal data from 1984-1999. Policies, legal regulations and individual behaviour have changed since that time, among them more employment-friendly family policies, but also increased female labour force participation rates and more dual earner households. This raises the question of whether and how the effects of marital disruption have changed since the turn of the millennium. In order to answer this question, we add the most recent waves (2000-2012) of the German Socio-Economic Panel (SOEP) study to our former data

3 Cash transfers or vouchers for buying child care services on the market would have the same effect.

4 However, it was unclear how these legal regulations were used by the beneficiaries and how they were enforced by the legal system. 
base and compare the period before and after 2000. Section 2 summarises the main features of the German welfare state model and how it changed in the last years. It also presents some stylised facts about recent socio-demographic changes of economic activity and household structures. Section 3 describes our data and methodology. Section 4 presents the results of our data analyses. Section 5 concludes with an overall assessment of the economic consequences of marital disruption in Germany.

\section{Theoretical background and research questions}

\subsection{The traditional German welfare state model}

The German welfare state was traditionally characterised by strong support for the male breadwinner family. This view is based on the following institutional features (Andreß/Bröcke/ 2007: 196-198):

- joint taxation of spouses imposing strong incentives to combine a large primary income, that is the breadwinner's income, with a comparatively small secondary income,

- a health insurance system insuring spouses and minors whose attachment to the labour market is marginal along with the household head without any extra contribution,

- $\quad$ pensions for surviving dependants being derived from the contributions of the head of the household without contributions of their own,

- family policies focusing on the traditional complete family and providing mostly cash benefits such as child allowances and family tax benefits that allow the average worker to support a larger family,

- a limited public child care infrastructure intended only to complement care work within the family, and

- a generous parental leave system motivating mothers to withdraw from the labour market for several years and exclusively care for their children.

These regime characteristics were combined with various legal safeguards for the economically-dependent family members in case a marriage breaks down ( $A n$ dreß/Bröcke/ 2007: 199-200):

- Parents have an obligation to support their children until the completion of education or training irrespective of their marital status (payments in kind by the resident parent and cash payments by the non-resident parent). The amount of cash payments depends on the child's age, the number of entitled persons (other children, previous spouse) and the liable person's income. Courts expect that the non-resident parent does everything possible to be able to pay the amount of child support that is set.

- Local youth welfare authorities intervene when a parent cannot or will not meet these responsibilities by helping to establish paternity, enforcing legal responsibility and advancing maintenance payments at a minimum level ("Regelunterhalt"). 
- Spousal support is restricted to specific circumstances pertaining to the former marriage, among them child care, interrupted educational or working careers, and a standard of living below the former standard during marriage ("Aufstockungsunterhalt").

- Marriage-specific changes in property can be equalised at the request of one spouse. Pension entitlements acquired during marriage must be equalised by the court (ex officio) in case of a divorce.

However, it was unclear whether and to what degree these regulations were being enforced by the legal system (Andreß/Bröckel 2007: 201-202). Moreover, it was questionable whether the liable persons would be sufficiently solvent to pay all claims even if this were the case. Liable persons are allowed to retain an amount for their basic needs, while the claimants' basic needs are not considered.

\subsection{What has changed in the institutional context?}

With respect to families' material well-being, the most important changes are:

1. an upgrading of the public child care infrastructure, especially in Western Germany, and especially for children aged under three,

2. a reform of the parental allowance (from "Erziehungsge/d" to "Elternge/d"),

3. a reorientation of minimum income policies with the so-called "Hartz" labour market reforms, and

4. increased expectations on women's self-supply in reformed German maintenance law.

Since 1996, as part of the law on child and youth welfare (Social Code - Sozialgesetzbuch - SGB - VIII), parents in Germany have had the legal right to enrol their children in a public day care institution. Originally, this right was only granted to children aged three and older, but it has been extended to children aged one and older since August 1, 2013. The law also states that the Youth Welfare Offices ("Träger der öfentlichen Jugendhilfe") of the districts and municipalities, based on the current demand for child care, have to provide the necessary infrastructure. Districts and municipalities receive money for this task from "their" federal state.

Although child and youth welfare is a task for the federal states in Germany, ${ }^{5}$ in the late 2000s, the German Federal Government launched a major initiative to support the expansion of the public child care infrastructure. Various legal regulations were adapted in 2008 (all collected in an omnibus act known as the Child Promotion Act "Kinderförderungsgesetz"), and an investment programme of about $12 \mathrm{bn} €$ was launched, of which the Federal Government paid about a third (BMFSFJ 2010). An omnibus act (known as the Day Care Expansion Act "Tagesbetreuungsausbaugesetz") was passed as early as 2005 , and this committed local authorities to provide an additional 230,000 child care places by 2010, especially in Western Germany. It

5 It is administered at local level (districts and municipalities), but financial support comes from the respective federal state. 
was decided in 2007 that there should be enough places to provide 35 percent of all children below the age of three with a care place by 2013.

Consequently, the German public child care infrastructure has greatly improved since the turn of the millennium in terms of size (number of places) and scope (age of children and opening hours) (see Table 1). Nevertheless, the number of places available is still considered insufficient, especially in large cities in Western Germany. The discrepancy between supply and demand has always been less severe in Eastern Germany due to the extensive child care infrastructure that had been built up in the former German Democratic Republic (GDR) and then taken over after reunification. Instead, a lack of job opportunities for women, due to the economic down-turn after reunification and later (comparatively) high unemployment rates, was more detrimental to women's careers in Eastern Germany than employment restrictions due to family obligations (see Section 2.3).

With its strong focus on the male breadwinner model, the former (Western German) Federal Republic of Germany (FRG) traditionally only needed public child care to complement mothers' care work on a part-time basis, while due to its socialistic ideology and labour shortages, the former GDR wanted women to participate in the labour market full-time and hence provided full-time child care from the very beginning. Today, with Western Germany catching up on Eastern German standards, there is no doubt that there is much more public support for child care than before 2000. All in all, the majority of political actors is convinced that the State should provide more opportunities for parents, and especially for mothers to continue employment despite child care obligations. This new policy orientation is also motivated by the understanding that the educational resources of some families (e.g. with respect to language education) are rather limited and should be supported in public child care facilities. However, the cultural dispute on how to organise child care in a modern world is far from being settled. Parts of the conservative political parties remain reluctant to provide more public child care, and are also demanding support for those who do not use this infrastructure (see the so-called "Betreuungsgeld" in footnote 7).

Starting from July 1979, parental care itself was remunerated with a special allowance (labelled as "Erziehungsgeld" from 1986 onwards) which provided a lump sum if the parent did not work more than part-time (max. 30 weekly working hours). Both the amount and the duration of the allowance have been increased in several steps since its introduction, ${ }^{6}$ and it was not counted against any minimum income support payments (e.g. social assistance "Sozialhilfe"). Politically, "Erziehungsgeld" was meant as a remuneration of the care work done at home by parents themselves. Together with the comparatively long periods of parental leave (up to three years), it was considered to have strong negative effects on the female labour sup-

6 Starting from January 1, 2004 (the most recent change), one could either receive $300 €$ for 24 months or $450 €$ for 12 months. On top of these payments, some federal states (Bavaria, Saxony and Thuringia; all traditionally governed by Christian Democratic parties) made additional support payments. 
ply (e.g. Aisenbrey et al. 2009; Drasch 2013), and hence to increase the economic risks after marital disruption for the caring parent, which in most cases was the mother. Moreover, it was criticised that such a low transfer income would not motivate better-educated women with higher labour incomes to have children. But it is especially this group of women that only has few children, if any. The "Elternge/d" was therefore introduced in 2007, replacing the former lump sum allowance with an allowance that is dependent on the labor income of the applying parent and is paid for one year immediately after the child's birth. "Elternge/d" is meant to replace labour income, and in doing so to also motivate high-income earners to have children. On the other hand, it is counted against minimum income support payments (in the beginning only partly, since 2011 completely), which compared to the former "Erziehungsgeld" is a clear impairment for low-income earners. Nevertheless, "Elternge/d" is a success story with a rising labour force participation of mothers with children aged between 1-2, namely from 33 percent in 2007 to 40 percent in 2010 (Wrohlich et al. 2012).

Germany also saw a major reform of its labour market and minimum income policies in 2004. Before that time, there was a separate minimum income payment for the long-term employed (unemployment assistance "Arbeitslosenhilfe - ALH"), which was merged with the general minimum income programme (social assistance "Sozialhilfe") in 2004 to form a common programme for all employable individuals. While the former ALH provided a monthly payment that was indexed to former earnings, the new "Arbeits/osengeld II - ALG II" provides monthly payments at the level of "Sozialhilfe". Moreover, both programmes are means-tested, i.e. they take partner incomes and economic wealth into account, but the exemptions with regard to partner income and wealth are much stricter in the ALG II programme. Even more importantly, besides means testing and lower payments, expectations concerning recipients' efforts to find new work, even at a lower level, have increased dramatically. Recipients have to sign target agreements with the job centre which can be enforced by lowered or interrupted payments in case of non-compliance. This "carrot and stick" policy has increased pressure to take up remunerative employment for all individuals who are currently unemployed but are in principle employable. Since our former analysis of marital disruption showed that the worst economic consequences were cushioned by minimum income payments (Andreß/Bröcke) 2007: 223), this policy change may also be effective for divorcees.

A similar change has taken place in family law. As mentioned in Section 2.1, a divorcee can request spousal support from the former spouse. Maintenance claims are restricted to specific circumstances of the former marriage, the most important

7 If the other parent also interrupts his/her employment to care for the child, the payment period is prolonged by two additional (partner) months. An additional lump sum allowance ("Betreuungsgeld") was introduced on February 15, 2013 based on an initiative by the conservative Christian Social Union (CSU). Starting from August 1, 2013, parents can receive a monthly payment of $100 €$ (from January 1, 2014: $150 €$ ) for up to 22 months after "Elterngeld" has expired if they do not take their child to a public (or publicly funded) child care institution and rather care for it at home or let someone else take care of it. 
one being child care (Andreß/Bröcke/ 2007: 200). Until 2008, the corresponding legal provision (section 1570 of the German Civil Code [Bürgerliches Gesetzbuch $B G B]$ ) mentioned no time limit for the claim. But since January 1, 2008, the amended section states that spousal support can be requested for three years following the birth of a child. An extension is only possible beyond that age if it is equitable. The decision on the extension must be based both on the needs of the child and on available child care facilities. Moreover, the family law case-law shows that the family courts are increasingly turning away from the male breadwinner model, and in most cases expect a dual earner family in which the wife also works in order to maintain her own economic independence (FamRZ 2009: 1391, 2010: 1024, 2011: 713, 2013: 248, 864). If career interruptions due to child care occur, they are assumed to be rather short-term, or even better to consist of jobs with reduced working hours. Correspondingly, court decisions on spousal support often only grant a fixed-term claim or a claim that reduces over time in order to accustom claimants to their lower standard of living after divorce (FamRZ: 2009: 1391, 2010: 344, 357; MDR 2012: 771).

Put differently, as in reformed minimum income programmes, a limited payment is guaranteed, but sooner or later the economically dependent spouse has to be self-reliant. ${ }^{8}$ Moreover, the latter expectation is often legitimised with the extended child care infrastructure. Hence, with respect to family affairs, we observe a gradual transition in the German welfare state after the turn of the millennium away from the conservative male breadwinner model and towards the Nordic welfare model that aims at providing equal opportunities for men and women; of course, at the cost of providing no specialised claims if economic independence is unequally distributed between spouses. ${ }^{9}$

\subsection{Changes in the economic behaviour of men and women}

Table 1 shows some selected data on economic activity, incomes, and child care for 1985-2013 which are mostly based on official statistics. While the employment rate of men hardly changed (except for the years with a high unemployment rate, around 78 percent of all men are gainfully employed), female labour force participation increased significantly, from less than 50 percent to almost 70 percent. This is also true, although at a lower level, for women with children below the age of 6. However, this increased economic activity is to a large extent based on parttime employment. Hence, if one measures female labour force participation in units equivalent to full-time positions, the corrected female employment rate actually decreases slightly, from 48 percent in 1992 to 46 percent in 2003 (Cornelißen 2005:

8 It should be noted however that the procedures to determine the amount of child or spousal support payments have not been changed, while the reform of minimum income programmes also included lower payments for the long-term unemployed.

9 For example, the law provides for spousal maintenance in Sweden, but in fact it is unusual to make such claims (Saldeen 1995: 493). 
Tab. 1: Selected statistics on economic activity, incomes, and child care (1985-2013)

\begin{tabular}{|c|c|c|c|c|c|c|c|}
\hline Indicator & 1985 & 1990 & 1995 & 2000 & 2005 & 2010 & 2013 \\
\hline \multicolumn{8}{|l|}{ a) Employment rate (aged $15-64)(\%)$} \\
\hline Men & 78.1 & 78.1 & 73.7 & 72.9 & 71.2 & 76.0 & 77.7 \\
\hline Women & 48.5 & 53.6 & 55.3 & 58.1 & 59.6 & 66.1 & 68.8 \\
\hline Women (with children aged below 6 ) & & & & & 46.7 & 54.6 & 60.5 \\
\hline \multicolumn{8}{|l|}{ b) Part-time employment (\%) } \\
\hline Men & 1.4 & 2.2 & 3.2 & 5.0 & 7.4 & 9.3 & 9.9 \\
\hline Women & 28.9 & 33.8 & 33.9 & 38.3 & 44.3 & 45.9 & 45.8 \\
\hline \multicolumn{8}{|l|}{ c) Unemployment rate (\%) } \\
\hline Men & 8.6 & 6.3 & 9.6 & 10.5 & 13.4 & 7.9 & 6.9 \\
\hline Women & 10.4 & 8.4 & 9.0 & 8.3 & 10.7 & 6.5 & 5.9 \\
\hline \multicolumn{8}{|l|}{ d) Earnings } \\
\hline Gross monthly earnings $(€)$ & & 1675 & 2018 & 2114 & 2230 & 2387 & 2594 \\
\hline Net monthly earnings $(€)$ & & 1174 & 1341 & 1411 & 1513 & 1610 & 1727 \\
\hline Real net earnings $(€)$ & & 1672 & 1666 & 1646 & 1636 & 1610 & 1634 \\
\hline Women's earnings as $\%$ of men's earnings & & & 21.0 & 21.0 & 22.0 & 23.0 & 22.0 \\
\hline e) Price index for housing costs $(2010=100)$ & & 59.5 & 75.1 & 83.0 & 90.9 & 100.0 & 107.5 \\
\hline \multicolumn{8}{|l|}{ f) Economic activity, couples with children (\%) } \\
\hline Man active/Woman not active & & & 40.0 & 36.8 & 33.3 & 30.4 & 29.5 \\
\hline Man r & & & 4.1 & 4.1 & 5.2 & 5.6 & 5.3 \\
\hline Man active/Woman active & & & 50.2 & 54.0 & 54.0 & 54.1 & 54.9 \\
\hline Man not active/ Woman not active & & & 5.8 & 5.2 & 7.5 & 9.9 & 10.3 \\
\hline \multicolumn{8}{|l|}{ g) Economic activity, couples w/o children (\%) } \\
\hline Man active/Woman not active & & & 20.0 & 18.2 & 17.5 & 16.3 & 16.6 \\
\hline Man not active/Woman active & & & 10.2 & 10.7 & 12.1 & 12.4 & 11.6 \\
\hline Man active/Woman active & & & 48.6 & 49.3 & 53.2 & 55.2 & 55.3 \\
\hline Man not active/ Woman not active & & & 21.2 & 21.8 & 17.2 & 16.1 & 16.6 \\
\hline \multicolumn{8}{|l|}{ h) Children in publicly funded child care (\%) } \\
\hline Western Germany: aged 0-3 & 1.6 & 1.8 & 2.2 & 4.2 & 7.7 & 17.3 & 24.2 \\
\hline Western Germany: aged 3-6 & 62.4 & 64.6 & 56.1 & 73.6 & 88.6 & 92.2 & 93.6 \\
\hline Eastern Germany: aged 0-3 & 49.8 & 54.2 & 41.3 & 37.0 & 37.0 & 48.0 & 49.8 \\
\hline Eastern Germany: aged 3-6 & & 89.9 & 84.8 & 87.1 & 93.2 & 95.2 & 95.6 \\
\hline
\end{tabular}

Note: Some statistics were not available for certain years. If they do not refer exactly to the year in the first row, we have chosen the closest value.

Sources: a Number of persons (females, males) aged 15-64 in employment as a share of the total population (females, males) of the same age group (Eurostat, http://epp.eurostat.ec.europa.eu/portal/ page/portal/statistics/search_database, retrieved 12 June 2014). ${ }^{\mathrm{b}}$ Number of employees reporting being part-time employed (until 1983: employees who work fewer than the agreed working hours for full-time employees) as a share of all employees (GESIS - Social Indicators Monitor (SIMon), Version 4/2014). ${ }^{C}$ Number of registered unemployed (until 1990: only Western German individuals) as a share of the dependent working population (SIMon, Version 4/2014). ${ }^{d}$ Earnings: gross and net nominal earnings (Statistisches Bundesamt 2014b), net earnings deflated with the consumer price index for Germany $(2010=100)$; gender pay gap: arithmetic mean of gross hourly wages of all female employees as a share of the corresponding mean for male employees (Statistisches Bundesamt 2012: 58; 2014a). ${ }^{\text {e }}$ Consumer price index for housing, water, electricity, gas, and other combustibles (Statistisches Bundesamt https://www.destatis.de/DE/ZahlenFakten/GesamtwirtschaftUmwelt/Preise/Verbraucherpreisindizes/Tabellen_/VerbraucherpreiseKategorien.html, retrieved 24 July 2014). ${ }^{f}$ Married couples and civil partnerships with at least one child aged below 18, data kindly supplied by Matthias Keller from the Federal Statistical Office (Keller/Haustein 2012: 58). 9 Married couples and civil partnerships without children, data see (e). h) SIMon (Version 4/2014) andStatistisches Bundesamt (2013). 
107). Nevertheless, due to this increased labour force participation, female unemployment has been lower than male unemployment since the mid-1990s.

The increase in female labour force participation was supported by a larger number of places for children in publicly funded child care facilities. While fewer than 5 percent of toddlers in Western Germany were taken care of in such institutions up to 2000 , the care rate for toddlers has now risen to 24.2 percent in 2013. This is not sufficient, but certainly much better than before the turn of the millennium. A similar positive development, fortunately on a much higher level, can be observed for preschool children in Western Germany. It is almost 100 percent in 2013, thus reaching a similar level to that in Eastern Germany. As has already been mentioned, due to its socialist heritage public child care was traditionally much more extensive in Eastern Germany, both for toddlers and for pre-school children. However, improved public child care is not the only explanation for higher female activity rates. Labour market reforms which provided increased opportunities for temporary and marginal work, structural change entailing a shift from employment in manufacturing to services, and changes in parental leave regulations (see Section 2.2), have also contributed to the rise in female employment.

This positive development is also consequential for the economic well-being of households and families. Although the gender pay gap has not changed significantly since the mid-1990s (women still earn roughly one-fifth less than men), increased female participation rates have significantly decreased the number of households in which only the man is economically active. According to the data from Table 1, the percentage of households where only the man was active fell by more than 10 percentage points for couples with children and almost 4 percentage points for couples without children. On the other hand, households where either both partners or only the woman was active increased in number. Hence, the male breadwinner model is not dying out, but it is certainly on the downturn. Earnings also increased for all employees by about 50 percent from the beginning of the 1990s until the end of our observation period. However, as the data on real earnings show, most of this increase is eaten up by inflation, thus severely limiting the purchasing power of the working population. While the overall increase in living costs has been modest in the observation period, it has been disproportionately high for housing (see the price index for housing costs in Table 1). Since marital breakup is often connected with residential mobility, this is an additional source of financial strain.

\subsection{Research questions and hypotheses}

We ask the same fundamental research questions as in our earlier analysis:

$Q_{1}$ : How considerable are the economic changes for married men and women with respect to separation and divorce?

$Q_{2}$ :Who cares for the children, and are the costs of child care covered by support payments from the non-resident parent?

$\mathrm{O}_{3}$ : Who moves out of the family home and how does this residential mobility affect the cost of living for mobile and immobile individuals? 


\section{$Q_{4}:$ How does marital disruption change the labour supply of men and women? \\ $Q_{5}:$ To what degree do separated and divorced individuals depend on their own gainful employment and private transfers, especially from the former spouse, and public transfers? \\ $Q_{6}:$ How does the division of tasks during marriage and the living conditions after separation (custody of children, existence of a new partner, gainful employ- ment) modify economic well-being after the break-up?}

The augmented data base however allows us to answer these questions more precisely and to add new questions about possible changes after the turn of the millennium. Due to the larger sample size, we are now able to control for the multivariate relationships between the former marriage model, children, new partners, and gainful employment in $Q_{6}$. Given the development of real earnings, we expect the economic consequences of marital disruption to be virtually the same as before the turn of the millennium $\left(H_{1}\right)$. With respect to possible gender inequalities, one could expect them to be less pronounced after the turn of the millennium due to women's increased economic activity. On the other hand, the discussion in Section 2.3 showed that this increase was based mostly on part-time or marginal employment. Hence, we specify a more cautious hypothesis and assume similar gender inequalities before and after the turn of the millennium $\left(H_{2}\right)$. Increased female labour force participation also implies that men are becoming increasingly dependent on women's incomes, and therefore that the economic consequences can also be negative for men, at least for some men $\left(H_{3}\right)$. Since recent amendments of family law lead one to expect the economically dependent spouse to be self-reliant earlier than before, we anticipate that spousal support payments will play a less significant role than in our former analysis $\left(H_{4}\right)$. Furthermore, having custody over children should be less detrimental to economic well-being after the break-up because a more extensive public child care infrastructure is available $\left(H_{5}\right)$. Finally, with respect to public transfers, we have no hypothesis as to whether their formerly quite important role in cushioning the economic consequences diminishes or decreases. On the one hand, we have seen a downsizing of some minimum income payments (e.g. ALH), but on the other hand, some new and quite lucrative support payments were introduced after the turn of the millennium (e.g., "Elterngeld").

\section{Data and Methodology}

\subsection{Sample}

The following analysis uses data from twenty-nine SOEP panel waves covering the period from 1984 to 2012 (Wagner et al. 2007). ${ }^{10}$ It focuses on the separation of married couples, since earlier analyses (Andreß/Güllner 2001) have shown that

\footnotetext{
10 The high income sample was excluded.
} 
separation results in greater economic changes than legal divorce, which follows separation, sometimes several years later when the economic situation has already stabilised. Separations were identified by combining information from the partner variables provided by the panel group at the German Institute for Economic Research (Berlin) and from survey questions about family status and life events (GülIner 2000). The year in which these separations are observed is defined by. Since we would like to compare the situation before and after these separations, data of at least one spouse have to be available for the years $t-1$ (before) and $t+2$ (after). Therefore, the unit of analysis is the corresponding separation in $t$, augmented by data from the years before and after the event. ${ }^{11}$

The data we use for the period before the turn of the millennium (1984-99) are slightly different from the data in our former analysis (Andreß/Bröckel 2007). ${ }^{12}$ Therefore, we compute all statistics anew (rather than copying them from the former publication) with in some cases slightly different results. After removing individuals who leave the panel in the year of separation, our sample contains data for 393 men and 446 women separating in 1984-1999 and 451 men and 560 women separating in 2000-12. Nearly two-thirds of these separated individuals become legally divorced within the observation period: 17 percent in the year of separation, 32 percent one year later, and 26 percent two years later. The remaining 25 percent take more than two and up to 19 years. It should also be noted that almost all the sample members are of working age (only 4 percent are older than 60 ). The following results are based on weighted data, using the cross-sectional SOEP weights that control for the sampling design, non-response, and panel attrition (see Andreß/Bröcke/ 2007: 204 for a discussion of the effects of panel attrition). ${ }^{13}$ Because men and women have different attrition rates, it is not guaranteed that both spouses are included in our analyses. For example, if we measure median household incomes before separation when both spouses were still living together, the corresponding values for men and women can be different because some spouses' data are missing.

\subsection{Income indicators}

Changes in income are a central focus of our analysis. The SOEP provides various income indicators for different time periods (month, year), at both individual and

\footnotetext{
${ }^{11}$ For certain analyses the longitudinal comparisons go even further than $t-1$ and $t+1$ (see below). If individuals experience several separations, only the first is included in the sample.

12 Firstly, in the former publication, all sample members were checked manually and missing partner information was added, thus resulting in a larger sample size for 1984-99. Secondly, and as will be explained later, we used a different base year for computing real incomes. Thirdly, incomes were expressed in DM, while now they are supplied in Euro even for the years prior to the introduction of the Euro in 2002. Fourthly, the data base has been revised with each new edition of the SOEP. Fifthly, our former measures of household income included imputed rents, while we are now using the housing costs specified by the respondents. Note also that the SOEP was extended to East Germany (the former GDR) in 1990. Hence, all data before 1990 come from West German respondents.

13 More specifically, we used the cross-sectional weight attached to the corresponding individual in the final year in which the individual contributed to our data.
} 
household levels. Given our interest in income redistribution by taxes, as well as by private and public transfers, we use data on yearly pre- and post-government household incomes as provided by the SOEP group in the PEQUIV file. Amongst other things, the PEQUIV file augments the detailed SOEP data on various income sources with imputed payroll and income taxes. The use of yearly pre- and postgovernment household incomes also has important implications for our longitudinal comparisons. Since the event of interest (separation) occurred at some point in time between the panel interview in $t$ and the preceding interview in $t$-1, yearly incomes from $t-1$ are not a valid indicator of the economic situation before the event. In many cases they already characterize the time of separation. Therefore, our income comparisons are based on data from $t-2$ and $t+1$. All selected cases were controlled for already living together with their spouse at $t-2$. Technically, things are even more complicated: Because yearly household incomes are based on retrospective questions, we use data from panel wave $t+2$ (including retrospective information for $t+1$ ) and panel wave $t-1$ (including retrospective information for $t-2$ ).

These household incomes include private transfers received by the household, but do not take into account private transfers paid to other individuals outside the household. Given the significance of private transfers for our research problem, a few remarks on the underlying survey questions are needed. Private transfers received are based on the so-called income calendar, which records the receipt of various income components for each month of the year preceding the interview, among them (support) payments from individuals outside the household (including payments from the advanced payment scheme for child maintenance). Though it is possible to distinguish from 2001 onwards between legal support payments made by the former spouse (including payments from the advanced child maintenance scheme) and other private transfers to the household (and in addition, from 2010 onwards, also between payments made by the former spouse and those payments received from the advance child maintenance scheme), we use private transfers as the sum of all these payments to make data comparable over the whole sample period. Thus, all private transfers received are included in PEQUIV pre-government household incomes, which then are subjected to the PEQUIV tax simulation programme to obtain post-government household incomes (after adding social security pensions and public transfers). Although the SOEP personal interview also includes a question about the amount of (support) payments being made for individuals outside the household in the year preceding the interview, this information is not used in the PEQUIV. It is however highly important for our analysis, and we have therefore deducted these support payments ${ }^{14}$ from PEQUIV post-government household incomes in order to obtain a measure of disposable household incomes for separated individuals. Given this procedure, it should be noted that private transfers received are taxed and include all kinds of sources, while private transfers that are paid are

14 The corresponding question distinguishes between different addressees (parents including parents-in-law, (former) spouse, children including son-in-law and daughter-in-law, other relatives, other non-related individuals). We have only used (support) payments for children and the former spouse. 
not taxed, but are restricted to the former family (children, spouse). Until 2000, the survey question asks for "donations from individuals outside the household, including payments from the advanced maintenance scheme." This includes gifts and other transfers from all private sources outside the household, as well as mandated child support and spousal support payments. From 2001 to 2009, private payments to the household can be additionally distinguished in terms of legal support payments from the former spouse (again including payments from the advance child maintenance scheme) as against other private payments. Support payments from the former spouse and payments from the advance child maintenance scheme are separately asked for from 2010 onwards. As discussed in Andreß and Bröckel (2007: 206), the amount paid by the liable person and that received by the entitled person do not agree, and there is no possibility to correct these discrepancies.

All household incomes were equivalised with respect to household size according to the formula:

$$
\text { equivalised household income }=\text { household income } / \text { size }^{\theta}
$$

These equivalised household incomes were then assigned to each individual in the household, and analyses were carried out on the individual level. A value of 0.5 was used for the elasticity parameter $\theta$, yielding moderate economies of scale with increasing household size similar to equivalence scales applied by the OECD (Buhmann et al. 1988). Using $\theta=1$, would yield per capita incomes and $\theta=0$ total household incomes. In our earlier analysis, $\theta$ is varied to check the sensitivity of the results against different assumptions concerning economies of scale. It subsequently emerged that gender inequalities persist irrespective of the equivalence scale that is used (Andreß/Bröcke/ 2007: 217).

When analysing incomes over such a long time-span as in our case, it is important to keep incomes comparable over time. Thus, we expressed all incomes in 2000 prices, using the official basket of commodities from the German Federal Statistical Office for 2005. The PEQUIV data supply an index which has been published by the German Federal Statistical Office and permits incomes to be expressed in 2005 prices. Our old study used incomes that were expressed in 1995 prices. Preliminary analyses with the data showed that using either one of the two indices is not without problems for our study. It emerged that expressing incomes in 2005 (1995) prices exaggerated (diminished) the level of incomes from the early (late) years of our observation period, and hence attenuated (aggravated) income changes. We decided to compromise by using the newer index but to rescale it to the base year 2000 .

\subsection{Methods}

The following analysis focuses both on the absolute value of various measures of economic well-being after separation and their change relative to their amount before separation. Consider the case of equivalised household income: let $l_{i, t-2}$ and $l_{i, t+1}$ be the equivalised household incomes of individual $i$ two years previously $(t-2)$ 
and one year after separation $(t+1)$. As a measure of change, we use the percentage change in equivalised household income for each individual:

$$
\% I_{i}=100 \cdot \frac{I_{i, t+1}-I_{i, t-2}}{I_{i, t-2}}
$$

Below, $\% l_{i}$ is termed a (percentage) change score of income. Because of the variance of economic changes (not all women lose and not all men win), we analyse the median, as well as the first and third quartiles of the distribution of change scores. We use violin plots to visualise the distribution of change scores. A violin plot is a combination of a box plot and a kernel density plot (Hintze/Ne/son 1998). Similar change scores were computed for other measures of economic well-being (e.g. housing costs).

In principle, quantile regression models can be used to compute confidence intervals and hypothesis tests for the median, first and third quartiles of the distribution of change scores. Again, preliminary analyses showed that the basic conclusions remain unchanged if one dichotomises change scores into gains $\left(\% l_{i} \geq 0\right)$ and losses $\left(\% l_{i}<0\right)$. Therefore, in order to test gender differences and changes after the turn of millennium, we use logistic regression to model the probability of a loss of income subsequent to separation: $\operatorname{Pr}\left(\% l_{i} \geq<0\right)$. Within these models it is also possible to control for some important changes in living conditions that take place in parallel to the separation of the two partners. The economic situation after separation naturally varies depending on whether the person is gainfully employed, has to care for children or lives together with a new partner. Moreover, it is important whether he or she was economically independent during the marriage. As an indicator of economic independence, we measure whether the person lived prior to separation in a household with a male breadwinner, a household in which the husband contributed the main but not the only income (termed "husband main earner household"), a dual earner household, or a household with a female breadwinner or main earner.

\section{$4 \quad$ Results}

We start with an analysis of gender-specific changes in child care, housing and employment (Sections 4.1-4.3), before turning to the more specific question of available incomes after marital disruption. Section 4.4 focuses on the effects of private and public income redistribution and analyses income changes caused by separation for men and women and for five different income concepts. Using equivalised disposable household incomes, Section 4.5 then controls for relevant living conditions parallel to the separation process.

\subsection{Children and support payments}

According to the most recent German time budget survey, mothers spend more than twice as much time with their children than their fathers do (BMFSFJ/Statis- 
tisches Bundesamt 2003: 22). This inequality continues when a marriage breaks down. As Table 2 shows, 61 percent of all women separating after the turn of the millennium live together with minor children (under the age of 18) after separation, while only 17 percent of all men do. ${ }^{15}$ Similar results are found for the period before 2000 and from representative surveys of divorced men and women (Andreß et al. 2003). If one compares the two periods, not much has changed, except that couples separating after the turn of the millennium have fewer children on average.

We can use the SOEP data to check whether these inequalities are compensated for by maintenance payments from the former husband. As already mentioned, the SOEP data do not make it possible to identify liable and entitled persons in a strict legal sense. But as described in Section 3.2, we can identify those individuals who receive and/or make support payments to other persons outside their own private household. According to the data shown in Table 2, only 33 percent of all men and 4 percent of all women give money to their children and/or former spouse after separation. Even when focusing exclusively on parents, only 38 percent of all fathers ( 3 percent of all mothers) make support payments. On the other hand, as few as 3 percent of all men and 26 percent of all women receive support payments. The figures are slightly higher for individuals living together with children after separation (men: 4 percent, women: 35 percent), but 65 percent of all women living together with children do not receive any support payments at all.

Has there been any change over time? It is difficult to give a definite answer. With respect to child support, the risk population has changed (fewer children; see above). When it comes to support payments received, these payments may originate from the former spouse, but also from other individuals and public transfers via the advance maintenance scheme (see the discussion in Section 3.2). From the data in Table 2, it seems as if men make fewer support payments (at least those living with children), while women living without children make more support payments. Given the aforementioned inaccuracies in the data, we hesitate to conclude that this is due to a lower economic potential of men and increased dependence on women's incomes.

Accordingly, private transfers comprise only a small part of household income after separation, much smaller than public transfers. As Table 2 demonstrates, private transfers only make a difference for women and constitute only 9 percent of their income package. Women's (and men's) economic situation after separation depends much more on public transfers. In the case of women, public transfers constitute more than one-third (39 percent) of their income package on average if they live together with children after separation. This proportion is smaller if one looks at all separated women (30 percent) or at men's household incomes (11 percent), but it is still a significant figure which increases with separation in all cases (from $t-2$ to $t+2$ ), except for men without children. We therefore concluded in our previous analysis

$\overline{15}$ After separation, these data may include children from a new partner. Between 2000 and 2012 (1984-1999 in brackets), 10 percent (13 percent) of all separated men and 10 percent (18 percent) of all separated women live together with minor children and a new partner one year after separation. 

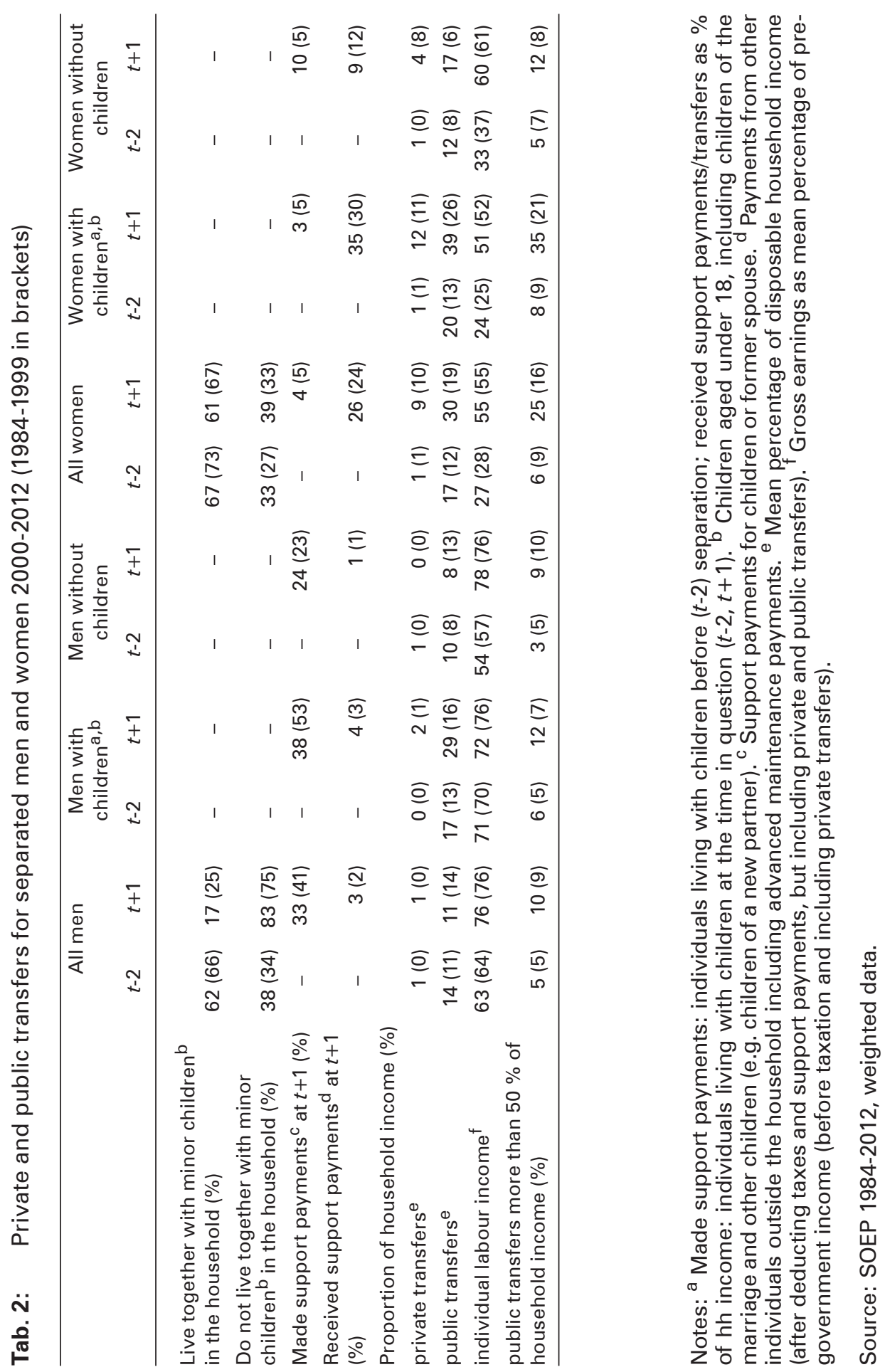
that "although a rather comprehensive system of (legal) maintenance regulations exists in Germany, it is not the former spouse who bears the main burden of income maintenance after separation" (Andreß/Bröcke/ 2007: 209). And this is obviously still the case after the turn of the millennium if one compares the data for the two periods in Table 2. It even looks as if this dependence on the public purse has increased over time. For example, before the turn of the millennium, public transfers made up 16 percent of men's and 26 percent of women's post-separation income package if they were living with children in their households. These percentages increased to 29 percent and 39 percent after 2000. Also the percentage of individuals where more than half of the income package consists of public transfers has increased by 5 percentage points (men) and 14 percentage points (women), respectively. But one has to take into account that after the turn of the millennium, income packages already consist to a higher degree of public transfers during marriage (see the percentage of public transfers at $t-2$ for all groups).

Although public transfers are of special policy relevance, one should not forget that, first and foremost, it is the separated individual who takes care of him- or herself through gainful employment (see below). Even in the case of women with children, about one-half (51 percent) of their income package comes from their own work income (cf. Table 2). Strictly speaking, average percentages of work income in Table 2 are not comparable with average percentages of private and public transfers. PEQUIV income data do not include net earnings that we could relate to our measure of net disposable household income (after taxation). We therefore used gross earnings as a percentage of pre-government household income (before taxation, but including private transfers). If one assumes that the tax rate is the same for earnings as for all other income components, the figures in Table 2 roughly indicate the (average) significance of earnings within the income package. Nevertheless, the number of individuals for whom public transfers are the main source of income (i.e. at least half of their disposable household income consists of public transfers) increases dramatically in all groups after separation, and especially so for women with children. This shows the importance of public transfers, at least for a subgroup of separated people.

\subsection{Residential mobility}

In our sample, 60 percent of all men and 62 percent of all women moved homes within two years after separating from their partner. In other words, the majority of both genders has to cope with residential mobility after separation. Focusing on individuals with minor children in the household after separation, the overall mobility rate is slightly lower, and noticeable differences exist between men (39 percent) and women (56 percent). "On the one hand," we argued, "this result is in accordance with the common assumption in divorce proceedings that children should stay in their familiar environment and not change homes. On the other hand, it is surprising that this is true especially for men and less so for women" (Andreß/Bröckel 2007: $210)$. We suspected that the higher mobility rate of women with children is partly a 
forced choice. Given their lower average incomes, they have to reduce the financial strain caused by separation by moving to smaller and hence less expensive homes.

We will analyse below whether this is still the case after the turn of the millennium. To that end, Table 3 looks beyond straightforward residential mobility and describes the concomitant changes in the size, quality and price of the home. The data are shown both in absolute $\left(\mathrm{m}^{2}\right.$, number of rooms, Euro) and relative terms (per household member, percentage of household income), and differentiate between men and women as well as between mobile and immobile persons. Again, we focus mainly on the data for 2000-2012, and only comment on the earlier period, when marked differences exist. Given the increase in housing costs (see Table 1), it is no surprise that respondents separating after the turn of the millennium report higher yearly housing costs than those separating in the years 1984-99. Part of this increase can also be explained by the fact that the first group lives in slightly larger homes than the second.

Just as before the turn of the millennium, mobile persons move to smaller and less expensive homes (fewer $\mathrm{m}^{2}$, fewer rooms, lower housing costs). Immobile persons, by definition, occupy the same home as before, and therefore have to manage to pay the costs of the former marital home from household incomes which are smaller in most cases. It may be possible to economise on utilities in some cases, or owner-occupied housing may become cheaper when mortgages have been paid off. But housing costs will remain the same for immobile persons in many cases. ${ }^{16}$ Immobile men spend 29 percent of their household income on housing after separation, while mobile men spend 22 percent. On the individual level, housing costs increase at least 27 percent for half of immobile men, while the median increase for mobile men actually equates to a decrease of 1 percent. Similar differences can be observed for immobile (+54 percent) and mobile women (+11 percent). Thus, by moving to less expensive homes, the separated individuals are able to reduce the financial strain caused by the household split at the expense of lower housing quality and a loss of neighbourhood contacts.

When interpreting these data with respect to possible gender differences, we have to remember the changes in household composition as described in the previous section. If children mostly stay with their mothers, average household size decreases more for men than it does for women, irrespective of their mobility status. In other words, women share their homes with more persons on average, even when they remain in the family home (see the size of the home and the number of rooms per household member in Table 3). The most important difference in our context, however, concerns the financial strain caused by the household split. In that respect, women always have to pay a larger portion of their household income

${ }^{16}$ A more differentiated analysis shows that the information provided by SOEP respondents on housing (size of home, housing costs, etc.) varies over time even for immobile individuals. This low reliability over time may explain, for instance, the slight differences in the reported size $\left(\mathrm{m}^{2}\right)$ of their homes or the fact that median housing costs fell in 2000-2012 (but not in 1984-1999). Altogether, however, we consider the statistics reported in Table 3 to be plausible and theoretically meaningful. 


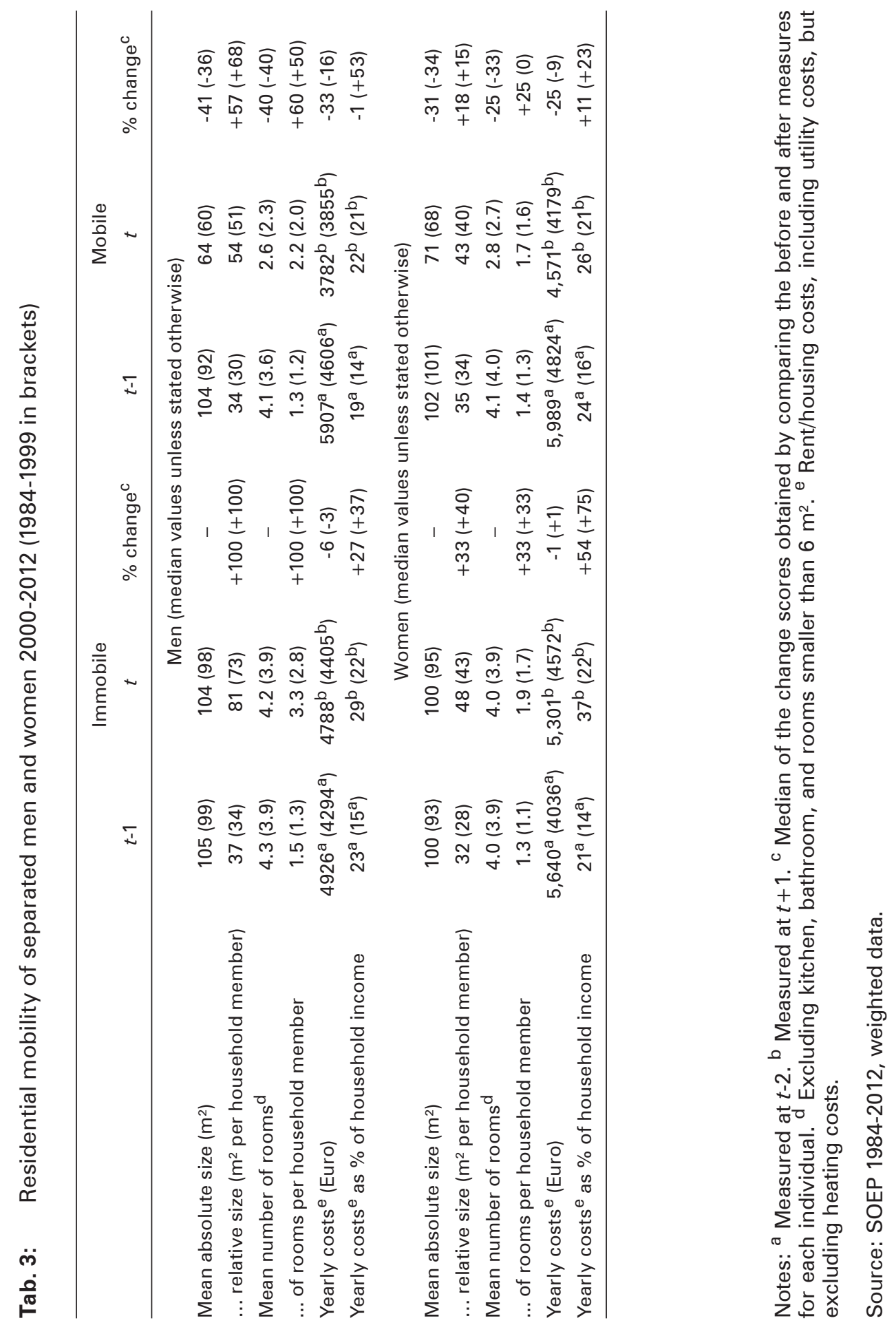


for their home than men, irrespective of whether they are mobile $(+4$ percentage points) or immobile (+8 percentage points). Before the turn of the millennium, there were hardly any gender differences with respect to housing costs as a percentage of household income. But because housing costs increased faster in the 1990s than in the 2000s (see Table 1), the median increase in relative housing costs for individuals separating between 1984 and $1999(+37$ percent and +53 percent for immobile and mobile men, +75 percent and +23 percent for immobile and mobile women) was much larger than after the turn of the millennium, where the median increase varied between -1 percent and 54 percent.

The hypothesis that residential mobility is a forced choice, especially for women, can be tested by comparing relative housing costs after separation with those during marriage. Both mobile men and women experience fewer increases in financial strain (men: -1 percent, women: +11 percent) than those men and women who remain in the family home (men: +27 percent, women: +54 percent) ${ }^{17}$ The figures (not shown in Table 3) are even more remarkable for women living with children: Relative housing costs increased for immobile women with children by +50 percent $(+76)$, while mobile women with children increased their relative housing costs by only +47 percent $(+32)$. These data suggest that residential mobility is partly enforced for women. This might also explain the comparatively high mobility rates of women with children, who contrary to the legal norms that have been mentioned leave their familiar environment more often than men with children.

\subsection{Employment}

Table 4 shows that, between 2000 and 2012, 91 percent of all men and 67 percent of all women (64 percent of all women with children) are either employed full-time, part-time or marginally before they separate from their spouses. Compared to the overall employment rates in Table 1, these are rather high rates of economic activity, especially for women. We are interested in finding out how these men and women adapt their employment status to the new situation after separation. Table 4 illustrates the corresponding changes in economic activity one year after separation. Some persons have extended their employment in the sense that former part-timers are now working full-time, or persons who formerly were not gainfully employed are now working at least irregularly or marginally. Since most men work

17 We observed a similar result for 1984-1999 in our earlier analysis (see Andreß/Bröckel 2007: 212). But our present replication shows an increase of +53 percent for mobile men, which compared to the earlier value (+25 percent) looks like a data or computation error. Extensive data checks showed that it is not a computation error. One explanation of the discrepancy may be a large sampling error due to the small sample size in this cell of the table (the change score is based on data at $t-2$ and is computed for a specific subgroup of men). Interestingly, mobile men have lower incomes after separation than immobile men do, which of course leads to aboveaverage increases in relative housing costs for mobile men, and may also explain the increase of +53 percent. We observe the opposite development for mobile women: Their incomes are higher after separation than the incomes of immobile women are, which leads to below-average increases in relative housing costs. 
Tab. 4: Employment and earned incomes for separated men and women 2000-2012 (1984-1999 in brackets)

\begin{tabular}{|c|c|c|c|c|c|c|}
\hline & \multicolumn{2}{|c|}{ Men } & \multicolumn{2}{|c|}{ All women } & \multicolumn{2}{|c|}{ Women with children ${ }^{a}$} \\
\hline & $t-2$ & $t+1$ & $t-2$ & $t+1$ & $t-2$ & $t+1$ \\
\hline \multicolumn{7}{|c|}{ Employment status ${ }^{\mathrm{b}}(\%)$} \\
\hline full-time & $88(86)$ & $84(81)$ & $28(36)$ & $38(41)$ & $16(22)$ & $24(25)$ \\
\hline part-time & $2(1)$ & $1(2)$ & $28(23)$ & $25(24)$ & $34(28)$ & $34(32)$ \\
\hline marginal & $1(0)$ & $1(0)$ & $11(4)$ & $10(3)$ & $14(6)$ & $9(4)$ \\
\hline training & $1(2)$ & $0(0)$ & $2(2)$ & $1(2)$ & $4(1)$ & $1(2)$ \\
\hline unemployed & $6(11)$ & $12(16)$ & $31(24)$ & $26(25)$ & $32(28)$ & $33(28)$ \\
\hline other & $2(1)$ & $1(0)$ & $0(11)$ & $0(6)$ & $0(16)$ & $0(9)$ \\
\hline \multicolumn{7}{|c|}{ Change in employment ${ }^{\mathrm{C}}(\%)$} \\
\hline decreased & & $9(11)$ & & $13(14)$ & & $16(15)$ \\
\hline no change & & $88(84)$ & & $57(59)$ & & $53(52)$ \\
\hline increased & & $2(6)$ & & $30(27)$ & & $31(33)$ \\
\hline Gross earnings $^{d}$ & 31.029 & 30.319 & 12.031 & 14.681 & 8.458 & 13.861 \\
\hline (Median, Euro) & $(28.976)$ & $(30.225)$ & $(15.062)$ & (18.557) & (11.095) & (16.251) \\
\hline \multicolumn{7}{|c|}{ Change in earnings ${ }^{\mathrm{e}}(\%)$} \\
\hline 1st quartile & & $-13(-7)$ & & $-6(-12)$ & & $-4(-5)$ \\
\hline median & & $2(5)$ & & $26(11)$ & & $36(26)$ \\
\hline 3rd quartile & & $14(22)$ & & $106(60)$ & & $225(96)$ \\
\hline
\end{tabular}

Source: SOEP 1984-2012, weighted data

full-time before separation, further increases of employment are hardly feasible (only 2 percent of all men report an increase), so that these kinds of change are mostly observed for women (30 percent report an increase), especially for women with children (31 percent). Given the predominance of full-time employment before separation, the opposite, namely a reduction of employment, is much more probable for men. However, this event is observed less frequently for men (9 percent report a decrease) than for women (13 percent; women without children: 16 percent). As we noted earlier, "this contradicts the prejudice often heard in public debates that men reduce employment in order to shirk maintenance payments for their spouse and children" (Andreß/Bröckel 2007: 213). All in all, women with children are the ones who change their activity status most frequently (47 percent report a change), mostly by increasing employment (31 percent).

Activity rates during marriage for individuals separating before the turn of the millennium are slightly lower (men: 87 percent, women: 63 percent, women with children: 56 percent), but still above the overall employment rates. As the data in 
Table 4 show, the increase in economic activity after the turn of the millennium is due to less unemployment for men and more part-time and marginal employment for women. This observation is very much in line with the overall development of the labour market (see Section 2.3 and Table 1). But the pattern of changes due to separation is not much different from the pattern after the turn of the millennium.

An important question is what these changes in economic activity mean in terms of earned incomes. We use yearly earnings before taxes measured in 2000 prices. Yearly data are chosen to make this analysis comparable with the following analyses of equivalised household incomes. Earnings before taxes are preferred to net earnings because we are interested in the effects of working hours and remuneration, and not in the question of how the State privileges or under-privileges changes in employment. Furthermore, the income tax bracket for married individuals changes one year after separation.

According to these data, the majority of men and women experience positive changes; and this is true both before and after the turn of the millennium. Due to their lower economic activity before separation, the increases in earnings are especially high for women (numbers for 1984-1999 in brackets): Half of them experience increases of +26 percent $(+11$ percent) and more, while the median increase for men amounts to +2 percent ( +5 percent). One the other hand, since women start from a much lower level, their earnings lag far behind men's despite the large increases. It should also be noted that not all men and women expand their economic activity in terms of earnings. One quarter of them has to deal with declining earnings of at least -13 percent (-7 percent) for men and -6 percent ( -12 percent) for women. But this should not distract us from the general conclusion that both genders predominantly try to expand their economic activity, which results in significantly increased earnings for women in most cases, albeit on a low level, and in minor positive changes for men.

Nevertheless, this positive picture is clouded if one compares the level of earnings before and after the turn of the millennium: Real earnings have hardly increased for men, and they are significantly lower for women in 2000-2012 than in the years prior to the turn of the millennium. We already know from our discussion in Section 2.3 that real earnings have tended to decrease rather than to increase in our observation period (see Table 1), and the stagnation of men's earnings therefore comes as no surprise. We also noticed that increased female labour force participation is to a large extent based on part-time and marginal employment, which is reflected in the activity patterns of our female sample members separating between 2000 and 2012 (see above). Part-time (and also marginal) jobs pay significantly less than full-time jobs (Statistisches Bundesamt/Wissenschaftszentrum Berlin für Sozialforschung 2013: 132), which may go at least some way towards explaining the lower female earnings after the turn of the millennium. ${ }^{18}$ Be this as it may, this result fits nicely

18 Of course, for a fair comparison of earnings before and after the turn of the millennium one would have to control for this and other job characteristics as well as for differences in human capital. 
with the earlier observation that public transfers play a much larger role in women's household incomes in 2000-2012 (see Section 4.1 and Table 2).

\subsection{Income and the effects of private and public redistribution}

According to the earnings indicator in Table 4, women's own income - at best amounts to half of men's own income from employment. It is therefore obvious that women, much more than men, need other sources of income to achieve the economic status that they had together with their husbands during marriage. On the other hand, men's economic status is not as high as these data suggest because part of their income will be transferred to their former wives and children after separation in the form of maintenance payments. To see the effects of private and public redistribution, we modelled this process in four steps: (1) factor incomes, (2) taxation, (3) payment and receipt of private transfers and (4) receipt of public transfers (including social security pensions).

For this analysis steps (3) and (4) could be reversed. For this analysis we used the following information from the PEQUIV: pre-government household incomes (hhpregov), post-government household incomes (hhposgov), private transfers received (hhprivat), public transfers (hhpublic). Additionally, we operationalized support payments being made for spouses and children (hhsupport) as described in Section 3.2. Post-government household incomes equal pre-government incomes minus taxes plus public transfers and social security pensions. Unfortunately, the PEQUIV includes private transfers received in pre-government household incomes, which are then subjected to a tax simulation programme. Support payments being made for spouses and children are not considered in the PEQUIV. In order to model private and public redistribution as the third and fourth steps, we had to deduct hhprivat and hhpublic from the corresponding PEQUIV household incomes. More specifically, we calculated the four redistributive steps as follows: $(1)=$ hhpregov - hhprivat, (2) = hhposgov - hhprivat - hhpublic, (3) = hhposgov - hhsupport - hhpublic, $(4)=$ hhposgov - hhsupport. Each of the results was then equivalized according to equation (1).

In a final step (5), we looked at disposable incomes (incomes at step iv) minus payments made for the home (i.e. rents, interest and amortisation payments for mortgages and utility costs, but excluding heating costs) to account for the financial strain resulting from residential mobility. Figure 1 shows, separately for men and women and for individuals separating before and after the turn of the millennium, the distribution of change scores observed at each step of this income redistribution process. The middle 50 percent of the distribution (ranging from the first to the third quartile) are indicated by a vertical fat blue line, the median change score by a white point, and the whole distribution by a kernel density plot. If the median change score is below (above) the horizontal red line of no change $\left(\% l_{i}=0\right)$, then the majority (more than 50 percent) experiences an income loss (gain).

Four observations are noticeable: Firstly, there are clear-cut gender differences at each step of the redistribution process. The female median change score is always lower than its male equivalent, indicating that separation implies less positive 
Fig. 1: $\quad$ Changes in equivalised household income for men and women separating in 1984-1999 and 2000-2012
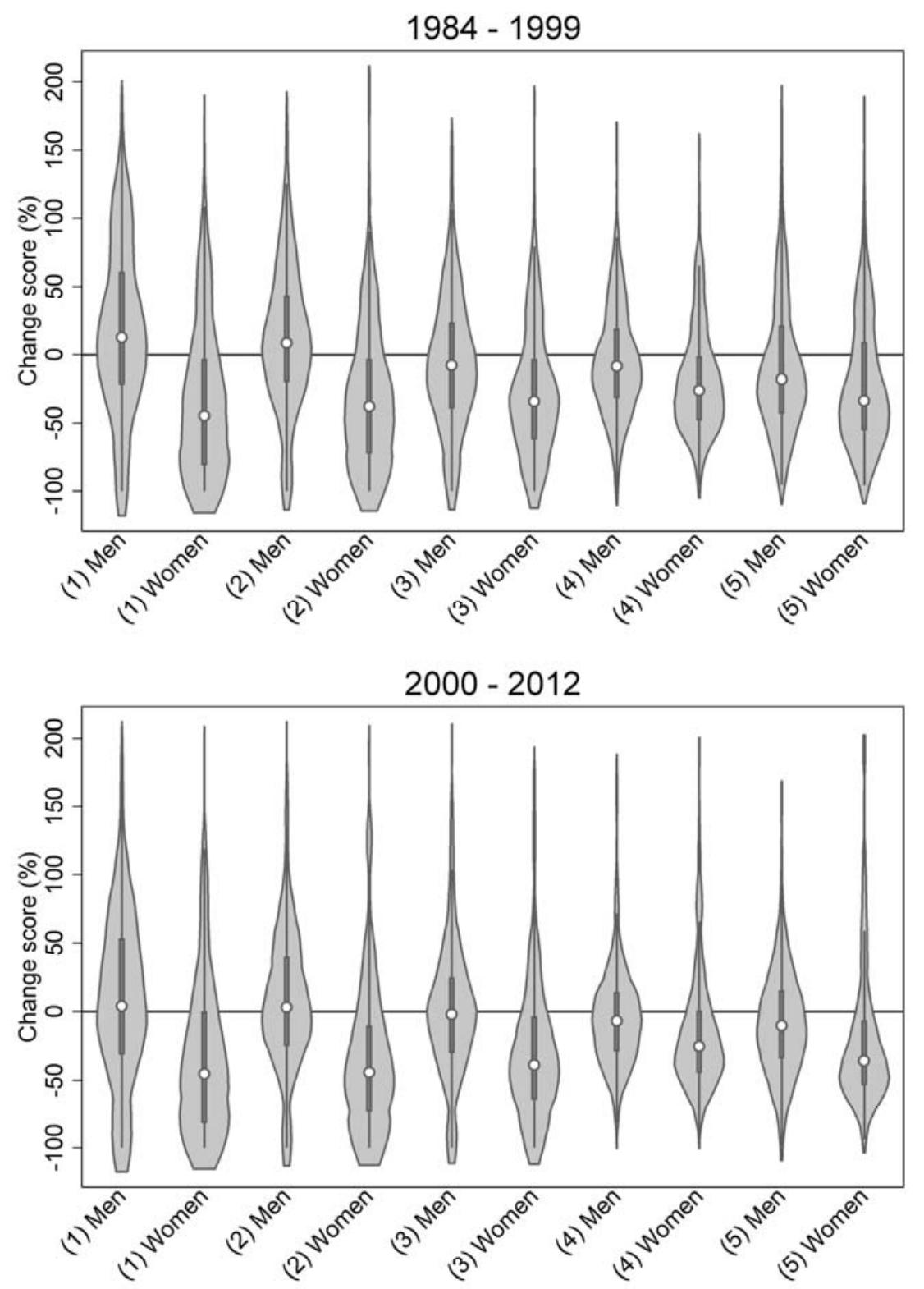

Notes: About 2 percent of all change scores top-coded at 200 percent. The distribution of change scores is shown for the following steps of the income redistribution process: (1) pre-government incomes, (2) ... minus taxes, (3) ... incl. private transfers, (4) ... plus public transfers, and (5) ... minus housing costs.

Source: SOEP 1984-2012, weighted data. 
and more negative income changes for women than for men. Secondly, the distribution of change scores is more skewed for women, with the mass of the change scores more in the lower than in the upper end of the distribution, while the men's distribution looks much more symmetrical. This again shows that the balance of positive and negative changes tends more in the negative direction for women than for men. However, thirdly, it seems as if these gender inequalities decrease with each step of the income redistribution process (see the distance between the female and male median change scores at each step in Fig. 1). In other words, taxation, support payments, and public transfers level out part of the gender inequalities. Taxation and support payments predominantly affect men: Their median change score drops when taxes are deducted from factor incomes (compare steps 1 and 2), and when private transfers have been paid and received (compare steps 2 and 3). Such a decrease is not visible for the women's median change scores. Note also that the female score increases slightly in step (4), when public transfers are added. No similar increase is visible for men. In step (5), when housing costs are paid, the median change score decreases again for both genders. Fourth/y, and finally, this pattern of income changes does not change dramatically over time. The violin plots for 1984-1999 and 2000-2012 look very much the same, except perhaps the male change scores in steps (1) and (2). They seem to be more positive in 1984-1999 (the median change scores are more clearly above the red reference line). But given the possibility of sampling errors, this may be an exaggeration. Therefore, in the next section, we will test the gender inequalities observed and possible changes over time for their statistical significance.

\subsection{Gender inequalities, different living conditions, and changes over time}

In a series of logistic regression models, we estimated the probability of experiencing a negative income change after separation (i.e. the probability of a negative change score). We analyse the probability of such income losses at each step of the income redistribution process (Models 1-5). Finally, at the level of disposable incomes (incomes at step 4), we control for various aspects of the respondents' living situation before and after separation (Model 6). Our main focus is on gender inequalities and changes over time between the two periods before and after the turn of the millennium. There has been some concern as to whether logistic regression coefficients can be compared across models; i.e. in our case, across different steps of the income redistribution process (Auspurg/Hinz 2011; Breen/Kar/son 2013; Breen et al. 2013; Karlson et al. 2012; Mood 2009). However, these concerns are not relevant for the interpretation of probabilities that are estimated from the regression coefficients (Long 1997: 50). The estimated probabilities are shown in Figure 2 and Table $5 .{ }^{19}$

19 The estimated logistic regression coefficients, from which these probabilities were computed, are shown in Table A1 in the Appendix. 
Fig. 2: Estimated probability of income loss after separation by gender and income concept (in percent)
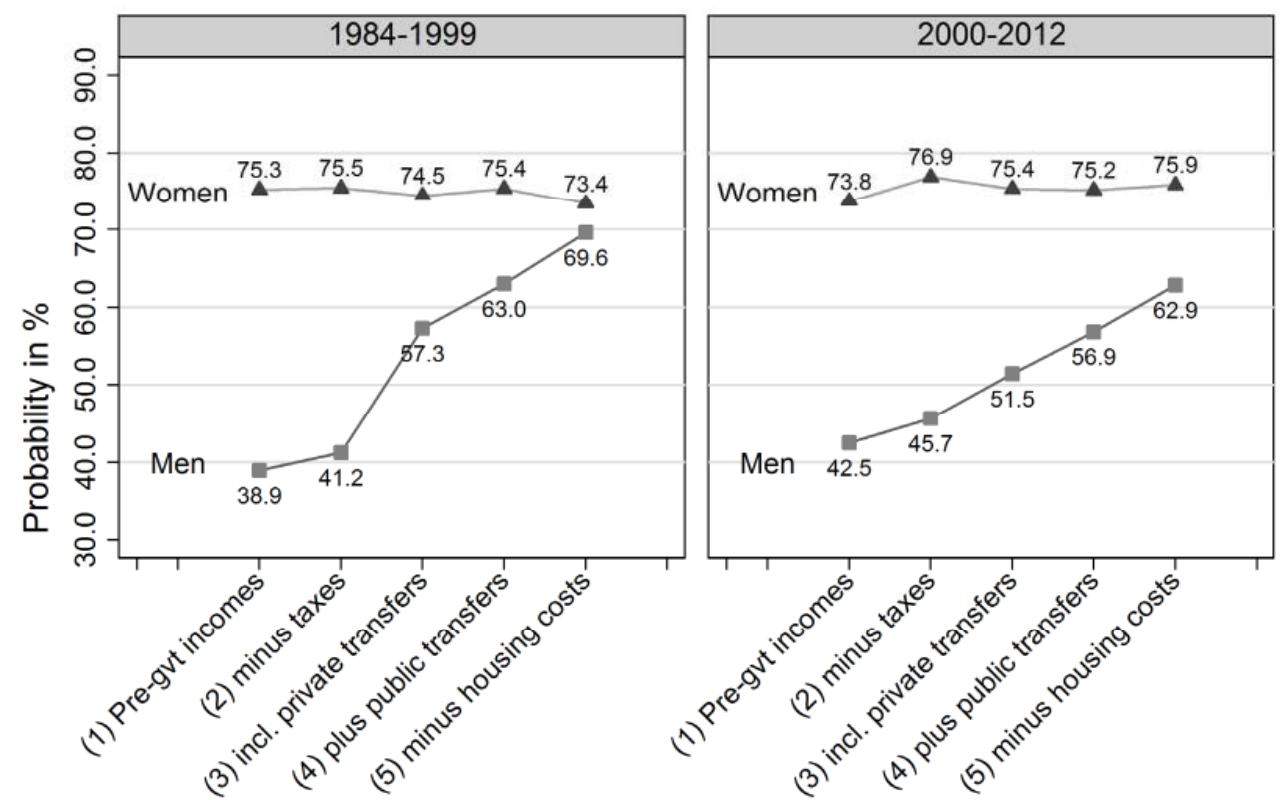

Notes: Probabilities for men (squares) and women (triangles) estimated from logistic regression models (Models 1-5, see Table A1 in the Appendix). Gender differences are significant $(\alpha=0.05)$ for each step of the income redistribution process except for disposable incomes minus housing costs (step v) in 1984-99.

Source: SOEP 1984-2012, weighted data, estimates based on logistic regression coefficients (Models 1-5, see Table A1).

The probability of an income loss amounts to approximately 75 percent for women before the turn of the millennium irrespective of whether one looks at factor or at disposable incomes (see Fig. 2). Neither private nor public transfers cushion these negative consequences of marital disruption. Moreover, there is no change for women after the turn of the millennium: The probability of income loss is still about 75 percent.

The situation is slightly better for men: At the level of factor incomes before and after taxation, only about 40 percent of all men experience an income loss; and this risk is almost the same before and after the turn of the millennium. However, if one takes private and public transfers into account, the situation becomes less favourable for men. The increasing estimates for men indicate that the probability of an income loss increases with each step of the income redistribution process. In other 
Tab. 5: Estimated probability of income loss after separation by living arrangement (in percent)

\begin{tabular}{|c|c|c|c|c|c|c|c|c|}
\hline \multirow[t]{3}{*}{ Group } & \multirow{2}{*}{$\begin{array}{c}\text { Before } \\
\text { separation } \\
t-2\end{array}$} & \multicolumn{3}{|c|}{ After separation } & \multicolumn{2}{|c|}{ 1984-1999 } & \multicolumn{2}{|c|}{$2000-2012$} \\
\hline & & & $t+1$ & & & & & \\
\hline & $\begin{array}{l}\text { Household } \\
\text { type }\end{array}$ & $\begin{array}{c}\text { New } \\
\text { partner }\end{array}$ & $\begin{array}{l}\text { Gainfully } \\
\text { employed }\end{array}$ & $\begin{array}{l}\text { Minor } \\
\text { children }\end{array}$ & Men & Women & Men & Women \\
\hline 1 & 2 & no & yes & no & 70.8 & 81.3 & 60.1 & $80.7^{b}$ \\
\hline 2 & 2 & yes & yes & no & $44.2^{\mathrm{a}}$ & $52.4^{a}$ & 51.3 & $55.4^{a}$ \\
\hline 3 & 2 & no & no & no & 65.4 & $93.8^{\mathrm{ab}}$ & 79.6 & $94.7^{\mathrm{a}}$ \\
\hline 4 & 2 & no & yes & yes & 69.6 & 70.7 & 65.5 & $90.1^{b c}$ \\
\hline 5 & 1 & no & yes & yes & 59.7 & $74.3^{b}$ & 43.8 & 80.2 \\
\hline 6 & 3 & no & yes & no & $83.3^{\mathrm{a}}$ & 89.3 & $72.2^{a}$ & $61.8^{C}$ \\
\hline 7 & 4 & no & yes & no & 48.6 & 60.5 & $74.3^{a}$ & 56.2 \\
\hline 8 & 1 & no & no & yes & 53.6 & $91.0^{\mathrm{b}}$ & 66.9 & $94.5^{b}$ \\
\hline
\end{tabular}

Notes: Household type: $1=$ male single earner, $2=$ male main earner, $3=$ dual earner, $4=$ female main or single earner. Significant effects with respect to ${ }^{a}$ the corresponding characteristic, ${ }^{b}$ gender for each period, and ${ }^{c}$ period for each gender $(\alpha=0.05)$. Tests based on linear restrictions on the logistic regression coefficients.

Source: SOEP 1984-2012, weighted data, estimates based on logistic regression coefficients (Model 6, see Table A1).

words, gender inequalities observed at the level of factor incomes decrease with each step. They even disappear (cease being significant) in 1984-1999, once we control for housing costs $\left(X^{2}=0.58, d f=1, p=0.45\right.$; all other differences are significant at the 5 percent level). ${ }^{20}$ This overall picture of decreasing gender inequalities appears in both observation periods, with two notable differences:

1. Before the turn of the millennium, the probability of an income loss for men increases notably, from 41.2 percent to 57.3 percent, if one takes private transfers into account. Since a similar increase is not visible after the turn of the millennium, it seems as if private transfers became less important for adjusting gender inequalities in economic well-being after 2000.

2. Contrary to the situation before the turn of the millennium, gender inequalities do not disappear once one controls for housing costs $\left(X^{2}=5.45, d f=1\right.$, $p=0.02$ ).

All in all, however, it would be wrong to conclude that gender inequalities are more quickly equalised before the turn of the millennium, given that none of the coefficients that tests for changes between the two observation periods is significant $(\alpha=0.05)$.

20 These and the following differences are tested by applying linear restrictions to the relevant parameters of the logistic regression model. 
A natural extension of this analysis is to ask how these income risks depend on men's and women's living situations before and after separation. Almost a quarter (23.8 percent) of all respondents lived in a traditional male breadwinner household during marriage in which the husband was the single earner. However, the most common ( 40.5 percent) household type was a "modernised" male breadwinner household in which the husband was the main earner, but not the only one. Dual earner households (22.4 percent), or households in which the wife was the main or even the single earner (13.3 percent), were less common. Given the increase in female labour force participation during the entire observation period (see Section 2.3), this distribution changed slightly after the turn of the millennium, with "modernised" male breadwinner households becoming more common (46.2 percent) at the expense of the traditional ones (17.9 percent). After separation, the most common living situation is being employed and living alone without a new partner and without any minor children ( 36.2 percent before and 42.9 percent after the turn of the millennium). The second most common living situation is almost identical, except for the fact that these men and women live together with minor children (21.4 percent before and 22.0 percent after the turn of the millennium). ${ }^{21}$ Only a minority lives together with a new partner (27.6 percent before and 21.6 percent after the turn of the millennium).

The first row of Table 5 shows the estimated probability of an income loss for the most common living situation before and after separation; i.e. men and women who have lived in a "modernised" male breadwinner household during marriage, but live alone and are unemployed after separation (termed group 1 or simply the reference group). The probabilities are derived from a logistic regression model regressing disposable incomes (incomes at step 4 neglecting housing costs) on selected aspects of the respondent's living situation before and after separation (see Model 6 in Table A1 in the Appendix). The probabilities in the first row basically tell the same story as Figure 2: An income loss is more probable for women, although the differences are not particularly pronounced at the level of disposable incomes that are shown here. The following rows 2-7 in Table 5 show how this pattern would change if one of the characteristics of this reference group were different (group 8 will be discussed later). For example, living together with a new partner after separation (group 2) has a significant positive effect both for men and women: All loss probabilities are smaller than in the reference group. Unemployment (group 3) increases the economic risks (except for men before the turn of the millennium), as does living with minor children (group 4) (but only after the turn of the millennium). On the other hand, separating from a traditional male breadwinner household entails fewer economic risks (group 5). The same is true for individuals separating from households in which the wife was the main or the single earner (group 7) (except for men after the turn of the millennium), while individuals separating from dual earner

21 This living situation is naturally more common among women, but differentiating between two observation periods, two genders and various living conditions results in highly differentiated subgroups of the data, which then provide highly unreliable information due to their small sample sizes. However, these more differentiated data are available from the authors on request 
households experience greater income losses (group 6) (except women after the turn of the millennium). But depending on the standard errors of the logistic regression coefficients, these descriptive differences may not be significant. Therefore, we formally tested whether there are significant changes if an individual in the reference group cohabits with a new partner, is gainfully employed, lives together with minor children, or experiences separation within another type of marital household. These tests are performed for each gender separately for each observation period, and a significant effect is indicated with the superscript (a) in the corresponding cell of Table 5.

Each row of Table 5 defines another subgroup of our sample. The values of all probabilities are however determined by the parameters of Model 6 that have been estimated by taking all subgroups into account (and not only the ones shown in Table 5). The tests apply linear restrictions on the relevant logistic regression coefficients of the model (cf. footnote 21), and hence test the overall effects of new partners, employment, parenting, and type of marital household for each gender and observation period. Group 8 is not included in these tests because it is different from the reference group with regard to several characteristics (and not just in terms of one characteristic as in the case of groups 2-7).

Based on these tests, we can safely say that cohabitation with a new partner reduces the income risks of separation (except for men after the turn of the millennium). Similarly, being gainfully employed after separation makes a significant (positive) difference; but only for women, possibly because most men are already gainfully employed before separation (see Section 4.3). Living together with minor children after separation has no effect, and this holds for both genders. Finally, the question of economic independence during marriage is also important for men. If they separate from a household where either both partners contributed an income or where the wife was the main or single earner, men's loss probability increases significantly (for men separating from female main/single earner households, the effect is only significant after the turn of the millennium).

Our main interest however lies in gender inequalities and changes over time. All in all, there are significant gender differences to the disadvantage of women in both periods. ${ }^{22}$ However, this overall picture does not necessarily hold true for all the subgroups in the sample. If it is true for groups $1-8$ in Table $5(\alpha=0.05)$, then the corresponding cell in Table 5 is marked with the superscript (b). According to these group-specific tests, women in the reference group faced significantly more economic risks before the turn of the millennium if they were unemployed (group 3) or if they separated within a traditional male breadwinner household (group 5). After the turn of the millennium, this is also true for all women in reference group 1 and who live together with minor children (group 4).

22 For 2000-2014 these differences are only significant at the 10 percent level, which is at odds with the tests for Figure 2, where they were significant at the 5 percent level. Note however that Model 6 is based on fewer observations than Model 4 (see Table A1 in the Appendix). 
With respect to changes over time, the overall tests show no significant differences for either men or women. Looking at the probabilities, this comes as no surprise: Period 2 probability is larger than its period 1 equivalent in some subgroups, whilst in others it is exactly the other way round. Moreover, if group-specific differences exist, they may not be significant. Nevertheless, some are significant $(\alpha=0.05)$, and this is indicated with the superscript (c) in the corresponding cell of Table 5 . The economic risks faced by women in the reference group who live together with minor children (group 4) have increased. On the other hand, if they have separated from a dual earner household (group 6), their economic risks have decreased.

Finally, Table 5 looks at a subgroup that includes all the high risk factors for women. Group 8 comprises individuals who separated within traditional male breadwinner households and are unemployed after separation while taking care of minor children without having a new partner. As expected, this situation implies significantly higher economic risks for women than for men. This living situation fortunately becomes less common for women compared to the 1960s and 1970s. About one woman in seven fell into this group during our observation period (1984-1999: 14.4 percent, 2000-2012: 13.2 percent).

\section{$5 \quad$ Summary and discussion}

Our analyses have shown that the economic consequences of divorce are still more negative for women than for men after the turn of the millennium. Even now it is the woman who takes care of the children in most cases, and the majority of these women does not receive any child support payments from their former spouse. But we should also mention that men receive virtually no support payments if they live together with minor children after separation. One man in three, but only one woman in twenty, makes support payments, be it for the children or the former spouse. Economically, support payments are of minor importance in the budgets of the separated individuals. Moreover, they play a less pronounced equalising role in the redistribution process after the turn of the millennium, as we expected in $\mathrm{H}_{4}$.

If one counts all private transfers from outside the household, which include the aforementioned support payments, these only constitute 1 percent of men's household incomes and 9 percent of women's household incomes. Private transfers only make a difference if women live together with minor children after separation. Nevertheless, they constitute only 12 percent of their household incomes. Contrary to our expectations in $H_{5}$, living together with minor children becomes a disadvantage for women after the turn of the millennium, and this is a clear change as against the situation pertaining prior to 2000 , when minor children did not increase the risk of income loss for either women or men. A more detailed analysis of the change scores shows that the change occurred in the upper tail of the distribution, and therefore for women with the least negative income changes. Before the turn of the millennium, the upper 25 percent of all women experienced a positive income change after separation of at least 8 percent, while after the turn of the millennium, they also experienced negative income changes of 17 percent at most. Given the 
expansion of the public child care system in the 2000s, this is a surprising result and needs further investigation. One possibility is that child care costs offset increases in earnings, although child care places are often free of charge for single mothers. The earnings increase after separation may also be negligible because women with minor children either do not increase their economic activity or choose marginal and part-time employment. It could also be the case that separated women with minor children make no use of public child care at all, or that it will still take some time until this infrastructural change becomes effective.

Public transfers are much more important than private ones, both for men and women. Dependence on public transfers is dramatic in some cases: One man in ten and one woman in four has to rely on a household income after separation in which public transfers make up more than half of the budget. Due to opposing changes in minimum income and family policies after the turn of the millennium, we refrained from hypothesising about the economic dependence of separated individuals on public transfers. But after comparing the data for our two observations periods, we have to conclude that economic dependence on public transfers increased for both genders after the turn of the millennium.

Both men and women try to ease the financial strain accompanying separation: on the one side by economising on consumption and on the other, by increasing their own economic activity. Cutting down on expenses is most visible with the most important cost factor: the residential home. Almost two-thirds of the spouses leave the family home after separation. Although they move to smaller and correspondingly less expensive homes, the increase in housing costs relative to their post-separation incomes is still considerable, but still lower than for those individuals who stay in the former family home. In a way, residential mobility after separation is a forced choice. This might also explain the comparatively high mobility rate of women with children. Contrary to the legal norm stating that children should stay in their familiar environment, they leave the family home more often than men with children. Expanding economic activity is a feasible option especially for women because only a minority works full-time before separation. This is not the case for men, who mostly work full-time before separation. But increased economic activity for women often means part-time or marginal work and significantly lower earnings than men. Hence, women need other sources of income besides their own labour income to maintain at least part of their former standard of living.

But even taking all sources of household income into account, our analyses showed that separation implies fewer positive and more negative changes in household income for women than for men. Some women naturally also experience positive changes, while some men suffer from income losses, but overall the balance of positive and negative changes runs more in the negative direction for women than for men. More refined tests showed that the changes in household income are significantly more negative for women than for men. Moreover, these inequalities persist if one controls for the economic situation of the former marital household and the living conditions after separation; i.e. whether the person has a new partner, lives together with minor children, and is gainfully employed. However, women's disadvantages become more slight with each step of the income redistribution pro- 
cess. They are greatest at the level of factor incomes, and become smaller when taxation, private and public transfers are taken into account. Finally, they actually become insignificant at the level of disposable incomes once we deduct housing costs, but only in 1984-1999. Hence, if one takes all the changes into account, including residential mobility, the economic consequences of divorce seem to be much more balanced between the genders than it appears at first sight.

Our larger data base also allowed us to scrutinize change over time in greater detail. On the whole, due to the overall stability of real earnings, we did not anticipate any change in the economic consequences of marital disruption $\left(H_{1}\right)$, and our hypothesis was clearly supported by our regression models. We did not expect any change with respect to gender inequalities because increased female labour force participation is based mostly on part-time and marginal jobs after the turn of the millennium. Correspondingly, the women in our sample mostly took up part-time and marginal jobs when they increased their economic activity. Therefore, as assumed in $\mathrm{H}_{2}$, we found no change of the gender inequalities after the turn of the millennium. Nevertheless, there are some instances of change: Men separating from dual earner households or from households where the woman was the main or even the single earner more often experienced negative changes after the turn of the millennium, although this risk was already visible for dual earner households in 1984-1999. In other words, in line with $H_{3}$, the effects of an increasing dependence on female incomes can be seen at least for some, though rather small subgroups of men. Moreover, economic independence pays for women whose economic risks of separation have decreased after the turn of the millennium if they have been living in a dual earner marital household. A distressing result is of course that cohabiting with minor children became more of a risk for women after the turn of the millennium than for men. More research is needed as to why recent policy changes towards more female employment and towards better reconciliation of family and work life are having so little effect on the economic consequences of marital disruption.

\section{References}

Aisenbrey, Silke; Evertsson, Marie; Grunow, Daniela 2009: Is There a Career Penalty for Mothers' Time Out? A Comparison of Germany, Sweden and the United States. In: Social Forces 88,2: 573-606 [doi: 10.1353/sof.0.0252].

Andreß, Hans-Jürgen; Bröckel, Miriam 2007: Marital disruption in Germany: Does the conservative welfare state care? Changes in material well-being and the effects of private and public transfers. In: Schmollers Jahrbuch 127,2: 193-226.

Andreß, Hans-Jürgen; Güllner, Miriam 2001: Scheidung als Armutsrisiko. In: Barlösius, Eva; Ludwig-Mayerhofer, Wolfgang (Eds.): Die Armut der Gesellschaft. Opladen: Leske + Budrich: 169-197 [doi: 10.1007/978-3-322-99629-9_6].

Andreß, Hans-Jürgen et al. 2006: The Economic Consequences of Partnership Dissolution - A Comparative Analysis of Panel Studies from Belgium, Germany, Great Britain, Italy, and Sweden. In: European Sociolgical Review 22,5: 533-560 [doi: 10.1093/esr/ jcl012]. 
Andreß, Hans-Jürgen et al. 2003: Wenn aus Liebe rote Zahlen werden. Über die wirtschaftlichen Folgen von Trennung und Scheidung. Wiesbaden: Westdeutscher Verlag.

Auspurg, Katrin; Hinz, Thomas 2011: Gruppenvergleiche bei Regressionen mit binären abhängigen Variablen - Probleme und Fehleinschätzungen am Beispiel von Bildungschancen im Kohortenverlauf. In: Zeitschrift für Soziologie 40,1.

BMFSFJ (Bundesministerium für Familie, Senioren, Frauen und Jugend) 2010: Information zum Kinderförderungsgesetz (KiföG) vom 13.07.2010 [http://www.bmfsfj.de/ BMFSFJ/gesetze, did=133282.html, 15.05.2014].

BMFSFJ (Bundesministerium für Familie, Senioren, Frauen und Jugend); Statistisches Bundesamt 2003: Wo bleibt die Zeit? Die Zeitverwendung der Bevölkerung in Deutschland 2001/02. Wiesbaden.

Breen, Richard; Karlson, Kristian Bernt 2013: Counterfactual Causal Analysis and Nonlinear Probability Models. In: Morgan, Stephen L. (Ed.): Handbook of Causal Analysis for Social Research. Springer Netherlands: 167-187 [doi: 10.1007/978-94-007-6094-3_10].

Breen, Richard; Karlson, Kristian Bernt; Holm, Anders 2013: Total, Direct, and Indirect Effects in Logit and Probit Models. [Article]. In: Sociological Methods \& Research 42,2: 164-191 [doi: 10.1177/0049124113494572].

Buhmann, Brigitte et al. 1988: Equivalence Scales, Well-Being, Inequality, and Poverty: Sensitivity Estimates across ten Countires using the Luxembourg Income Study (LIS) Database. In: Review of Income and Wealth 34: 115-142 [doi: 10.1111/j.1475-4991.1988. tb00564.x].

Cornelißen, Waltraud 2005: Gender-Datenreport. Erster Datenreport zur Gleichstellung von Frauen und Männern in der Bundesrepublik Deutschland im Auftrag des Bundesministeriums für Familie, Senioren, Frauen und Jugend. München: Deutsches Jugendinstitut e.V. in Zusammenarbeit mit dem Statistischen Bundesamt.

Drasch, Katrin 2013: The re-entry of mothers in Germany into employment after family-related interruptions. In: IAB-Bibliothek 343 (Dissertationen). Bielefeld: WBV [doi: $10.3278 / 300813 w]$.

FamRZ, Zeitschrift für das gesamte Familienrecht mit Betreuungsrecht, Erbrecht, Verfahrensrecht, Öffentlichem Recht, various editions.

Güllner, Miriam 2000: Analyse familiärer Ereignisse (Trennung, Scheidung, Tod) mit Daten des Sozio-oekonomischen Panels. Bestimmung der Untersuchungs- und Vergleichsgruppen anhand der Längsschnittdatei "alleWellen_long.sav". Bielefeld: Arbeitspapier Nr. 2 des Forschungsprojektes "Die wirtschaftlichen Folgen von Trennung und Scheidung für Familien" im Auftrag des Bundesministeriums für Familie, Senioren, Frauen und Jugend [http://eswf.uni-koeln.de/forschung/wts/].

Hintze, Jerry L.; Nelson, Ray D. 1998: Violin Plots: A Box Plot-Density Trace Synergism. In: The American Statistician 52,2: 181-184 [doi: 10.1080/00031305.1998.10480559].

Holden, Karen C.; Smock, Pamela J. 1991: The Economic Costs of Marital Dissolution: Why Do Women Bear a Disproportionate Cost? In: Annual Review of Sociology 17: 51 78 [doi: 10.1146/annurev.so.17.080191.000411].

Karlson, Kristian Bernt; Holm, Anders; Breen, Richard 2012: Comparing Regression Coefficients Between Same-sample Nested Models Using Logit and Probit: A New Method. In: Sociological Methodology 42,1: 286-313 [doi: 10.1177/0081175012444861].

Keller, Matthias; Haustein, Thomas 2012: Vereinbarkeit von Familie und Beruf. Ergebnisse des Mikrozensus 2010. In: Wirtschaft und Statistik 2012 (Januar): 30-50. 
Kenny, Lawrence W. 1983: The Accumulation of Human Capital During Marriage by Males. In: Economic Inquiry 21: 223-231 [doi: 10.1111/j.1465-7295.1983.tb00627.x].

Long, J. Scott 1997: Regression models for categorical and limited dependent variables. Thousand Oaks: Sage.

$M D R$, Monatsschrift für Deutsches Recht, various editions.

Mood, Carina 2009: Logistic Regression: Why We Cannot Do What We Think We Can Do, and What We Can Do About It. European Sociological Review, 26(1), 67-82 [doi: 10.1093/esr/jcp006]

Saldeen, Ake 1995: Family Law in Sweden. In: Hamilton, Carolyn, Standley, Kate; Hodson, D. (Eds.): Family Law in Europe. London/Dublin/Edinbourgh: Butterworth: 472 510.

Sørensen, Annemette 1994: Women's Economic Risk and the Economic Position of Single Mothers. In: European Sociological Review 10: 173-188.

Statistisches Bundesamt; Wissenschaftszentrum Berlin für Sozialforschung 2013: Datenreport 2013. Ein Sozialbericht für die Bundesrepublik Deutschland. Bonn: Bundeszentrale für politische Bildung.

Statistisches Bundesamt 2012: Indikatorenbericht 2012 - Nachhaltige Entwicklung in Deutschland. Wiesbaden: Statistisches Bundesamt.

Statistisches Bundesamt 2013: Statistiken der Kinder- und Jugendhilfe. Kinder und tätige Personen in Tageseinrichtungen und in öffentlich geförderter Kindertagespflege am 01.03.2013. Wiesbaden: Statistisches Bundesamt.

Statistisches Bundesamt 2014a: Gender Pay Gap 2013 bei Vollzeitbeschäftigten besonders hoch. Pressemitteilungen des Statistischen Bundesamtes. Retrieved from https://www.destatis.de/DE/PresseService/Presse/Pressemitteilungen/2014/03/ PD14_104_621.html, 12.02.2015).

Statistisches Bundesamt 2014b: Volkswirtschaftliche Gesamtrechnungen. Fachserie 18, Reihe 1.1. Wiesbaden: Statistisches Bundesamt.

Wagner, Gert G.; Frick, Joachim R.; Schupp, Jürgen 2007: The German Socio-Economic Panel Study (SOEP) - Scope, Evolution and Enhancements. In: Schmollers Jahrbuch 1271: 139-169 [doi: 10.2139/ssrn.1028709].

Wrohlich, Katharina et al. 2012: Elterngeld Monitor: Endbericht; Forschungsprojekt im Auftrag des Bundesministeriums für Familie, Senioren, Frauen und Jugend. In: DIW Berlin - Politikberatung kompakt 61.

Miriam Bröckel. Universität Bielefeld, SFB 882 Von Heterogenitäten zu Ungleichheiten. Bielefeld, Germany. E-Mail: miriam.broeckel@uni-bielefeld.de URL: https://ekvv.uni-bielefeld.de/pers_publ/publ/PersonDetail. jsp?personld=27030353\&lang=en

Prof. Dr. Hans-Jürgen Andreß ( $\varangle)$. Universität zu Köln, Wirtschafts- und Sozialwissenschaftliche Fakultät, Institut für Soziologie und Sozialpsychologie (ISS). Köln, Germany. E-Maill: hja@wiso.uni-koeln.de

URL: http://www.iss-wiso.uni-koeln.de/andress.html?\&L $=0$ 


\section{Appendix}

We estimated a series of logistic regression models. The most complex Model 6 is defined as follows:

$$
\ln \frac{\operatorname{Pr}\left(\% l_{i}<0\right)}{1-\operatorname{Pr}\left(\% l_{i}<0\right)}=X \alpha+G \cdot X \beta+P \cdot X Y+G \cdot P \cdot X \delta
$$

$G$ and $P$ are dummy variables indicating females $(G=1)$ and the second observation period $(P=1)$. $X$ is a row vector of covariates. In case of Models 1-5, the vector $X$ only includes a "variable" equal to one. In Model 6 it also includes dummies for new partner, gainful employment, and cohabitation with minor children. $\alpha, \beta, \gamma$, and $\delta$ are suitable column vectors of regression coefficients. Their estimates are shown in columns 3-6 of Table A1.

Tab. A1: Log-odds of income loss after separation (logistic regression coefficients)

\begin{tabular}{|c|c|c|c|c|c|c|c|}
\hline \multirow[t]{3}{*}{ Model } & \multirow[t]{3}{*}{ Variables } & \multicolumn{2}{|c|}{ 1984-1999 } & \multicolumn{2}{|c|}{$2000-2012$} & \multirow{3}{*}{$n$} & \multirow{3}{*}{ Pseudo $R^{2}$} \\
\hline & & Men & Women & Men & Women & & \\
\hline & & $\alpha$ & $\beta$ & $\gamma$ & $\delta$ & & \\
\hline 1 & (1) Pre-government incomes & $-0.4497^{* *}$ & $1.5636 * * *$ & 0.1477 & -0.2280 & 1362 & 0.090 \\
\hline 2 & (2) $\ldots$ minus taxes & $-0.3545^{*}$ & $1.4807 * * *$ & 0.1802 & -0.1021 & 1362 & 0.087 \\
\hline 3 & (3) ... incl. private transfers & $0.2938 *$ & $0.7786^{* * *}$ & -0.2355 & 0.2841 & 1362 & 0.037 \\
\hline 4 & (4) $\ldots$ plus public transfers & $0.5341 * * *$ & $0.5880^{* *}$ & -0.2577 & 0.2466 & 1362 & 0.023 \\
\hline 5 & (5) ... minus housing costs & $0.8295^{* * *}$ & 0.1879 & -0.3028 & 0.4336 & 1168 & 0.009 \\
\hline \multirow[t]{7}{*}{6} & Reference group ${ }^{a}$ & 0.1995 & $2.7017^{* * *}$ & 0.2740 & -1.1148 & 916 & 0.123 \\
\hline & New partner $(t-1)$ & $-1.1203^{* *}$ & -0.2513 & 0.7622 & -0.5998 & & \\
\hline & Gainfully employed $(t+1)$ & 0.2498 & $-1.5024^{*}$ & -1.2029 & 1.0072 & & \\
\hline & Living with children $(t+1)$ & -0.0568 & -0.5312 & 0.2888 & 1.0830 & & \\
\hline & Husband main earner $(t-2)$ & 0.4363 & -0.6178 & 0.4520 & 0.5450 & & \\
\hline & Dual earner $(t-2)$ & $1.1606^{*}$ & -0.6911 & 0.2758 & -0.8752 & & \\
\hline & Wife single/main earner $(t-2)$ & -0.5039 & -0.7167 & $2.0449 *$ & -1.1856 & & \\
\hline
\end{tabular}

Notes: ${ }^{a}$ Men separating between 1984 and 1999 from a male breadwinner household, without a new partner, not gainfully employed, and living without minor children after separation. ${ }^{*} p<0.05,{ }^{* *} p<0.01,{ }^{* * *} p<0.001$.

Source: SOEP 1984-2012, weighted data. 


\section{Comparative Population Studies}

WWW.comparativepopulationstudies.de

ISSN: 1869-8980 (Print) - 1869-8999 (Internet)

Published by / Herausgegeben von

Prof. Dr. Norbert F. Schneider

Federal Institute for Population Research

D-65180 Wiesbaden / Germany

\section{Managing Editor /}

Verantwortlicher Redakteur

Frank Swiaczny

\section{Assistant Managing Editor /}

\section{Stellvertretende Redakteurin}

Katrin Schiefer

\section{Copy Editor (German) /}

Lektorat (deutsch)

Dr. Evelyn Grünheid

\section{Layout / Satz}

Beatriz Feiler-Fuchs

E-mail:cpos@bib.bund.de

\section{Scientific Advisory Board /}

Wissenschaftlicher Beirat

Paul Gans (Mannheim)

Johannes Huinink (Bremen)

Michaela Kreyenfeld (Rostock)

Marc Luy (Wien)

Clara H. Mulder (Groningen)

Notburga Ott (Bochum)

Peter Preisendörfer (Mainz)

Zsolt Spéder (Budapest)
Board of Reviewers / Gutachterbeirat Martin Abraham (Erlangen)

Laura Bernardi (Lausanne)

Hansjörg Bucher (Bonn)

Claudia Diehl (Konstanz)

Andreas Diekmann (Zürich)

Gabriele Doblhammer-Reiter (Rostock)

Jürgen Dorbritz (Wiesbaden)

Anette Eva Fasang (Berlin)

E.-Jürgen Flöthmann (Bielefeld)

Alexia Fürnkranz-Prskawetz (Wien)

Beat Fux (Salzburg)

Joshua Goldstein (Berkeley)

Karsten Hank (Köln)

Sonja Haug (Regensburg)

Hill Kulu (Liverpool)

Aart C. Liefbroer (Den Haag)

Kurt Lüscher (Konstanz)

Emma Lundholm (Umeå)

Nadja Milewski (Rostock)

Dimiter Philipov (Wien)

Roland Rau (Rostock)

Tomáš Sobotka (Wien)

Jeroen Spijker (Barcelona)

Olivier Thévenon (Paris)

Helga de Valk (Brussel)

Heike Trappe (Rostock)

Michael Wagner (Köln) 